\title{
SERVICES OF ECONOMIC DEVELOPMENT ORGANISATIONS IN GYÖR
}

\section{A GAZDASÁGFEJLESZTÉSI TEVÉKENYSÉGET FOLYTATÓ SZERVEZETEK SZOLGÁLTATÁSAI GYŐRBEN}

\author{
Adrienn REISINGER ${ }^{\mathrm{a}}$, Petra KECSKÉS ${ }^{\mathrm{b}}$, Katalin CZAKÓ \\ ${ }^{a}$ Széchenyi István University, Hungary, Győr, Egyetem tér 1.radrienn@sze.hu \\ ${ }^{\mathrm{b}}$ Széchenyi István University, Hungary, Győr, Egyetem tér 1. kecskes.petra@sze.hu \\ ${ }^{\mathrm{c}}$ Széchenyi István University, Hungary, Győr, Egyetem tér 1. ckatalin@sze.hu
}

Cite this article: Reisinger, A., Kecskés, P., Czakó, K. (2017). Services of Economic Development Organisations in Győr. Deturope, 9(3):85-100.

\begin{abstract}
Economic development of a municipality is highly depended on organizations and institutions, which services target local entrepreneurs and other economic actors. In the summer of 2015 we have collected and mapped the services of organizations with the function of economic development in the Hungarian city, Györ. Through our research we could identify the services and the characteristics of linkages and cooperation of the economic development organizations (EDOs). Most important findings of the study are the followings: activity of the organizations has a wide range. Some of them are presented in more organizations at the same time. Level of diversification is quite low. Directions of cooperation are mainly based on personal or ad hoc relations. We conducted that EDOs know about each other, despite of this fact the number of linkages is low. In this paper we provide findings about Györ, but the results can be used for other settlements' economic development, too.
\end{abstract}

Keywords: local economic development, economic development organisations (EDOs) services, supply, cooperation

\section{Összefoglaló}

Egy település, térség gazdaságfejlesztéséhez nagy mértékben hozzá tudnak járulni azok a szervezetek is, melyek szolgáltatásaikkal segíteni tudják a helyi vállalkozások és egyéb gazdasági szereplők fejlődését. 2015 nyarán egy konkrét megyei jogú város - Győr - esetében feltérképeztük a gazdaságfejlesztési tevékenységet folytató szervezeteket, majd interjúk segítségével azonosítottuk a megkérdezett szervezetek szolgáltatásait és együttmüködési jellemzőit. A tanulmány legfontosabb megállapítása, hogy a megkérdezett szervezetek tevékenysége széles körü, de sok esetben párhuzamosan több szervezetnél is elöfordulóak, illetve nem diverzifikáltak. A szervezetek közötti kapcsolattartás föként személyekhez kötődik, a szereplök tudnak egymásról, de az együttmüködési felületek száma kevés. Eredményeinek Győr kapcsán mutatjuk be, azonban az itt szerzett tapasztalatok hasznosíthatók más települések gazdaságfejleztő tevékenysége során is.

Kulcsszavak: helyi gazdaságfejlesztés, gazdaságfejlesztő szervezetek, szolgáltatás, kínálat, együttmüködés 


\section{INTRODUCTION}

Organizations which support the local firms and other economic actors with their services can contribute to the economic development of a given settlement and region. Such organizations are the economic development organizations (EDOs). The objective of this study is to explore these organizations, to introduce and process their services and to describe their cooperation attributes through on a given case in the town of Györ, Hungary.

There is a need to discuss and evaluate the role and efficiency of EDOs in any region of Hungary. Our case is the city of Györ, which can be a representative field of research. Györ is not in the capital region of Hungary, but due to its dynamically growing economic atmosphere it is worth to elaborate details of the above mentioned topic. Györ has prosperous industry, mainly focuses on the automotive sector but also famous for its lively cultural and sport life. Beside this the presence of the university is getting continuously stronger. According to Rechnitzer (2016) the city's size, its historical and industrial area and its milieu itself make it possible to have deeper insight to the issues connected to local businesses. Just to highlight the related academic data: the city has about 130 thousand inhabitants and more than 40 thousand firms are operating in Györ. According to current statistical summary of Czakó (2017) region ${ }^{15}$ of Győr has outstanding values in the following fields:

- unemployment rate;

- gross monthly earnings of full-time employees;

- the number of registered enterprises per thousand inhabitants;

- investments per capita;

- industrial production per capita;

- construction per capita production;

- decrease in the number of registered partnerships.

In 2014 the business tax could be reduced by $10 \%$, for 2016 the increase was realized by $11 \%$. Rate of the Hungarian owned companies are $89 \%$. Due to the above mentioned data, this region can take special potentials supporting the effective operation of local EDOs.

A semi-structured interview survey was implemented with EDOs in the town of Györ, in the framework of a research program. The focus of the research was the analysis of the supply

\footnotetext{
${ }^{15}$ Based on statistics of West Transdanubian Region.
} 
side of the local development services. In other words: to represent the supply map of the local development services.

In the framework of this research 14 organizations took part on a detailed interview. According to the research conditions we could reach all EDOs in Györ. The research and its findings can provide a sample to other settlements and/or other regions to foster economic growth by expanding the supply activities of EDOs.

In the first section, a brief theoretical overview will be demonstrated about local economic development, relating to its means and actors, and the role of EDOs. It should be highlighted that the aim of the study is not to describe the theoretical background of the topic in details, but to focus on the specific findings of the conducted research as case studies. The foremost statement of the paper is that the activities of the interviewed organizations are extensive; however, activities are often offered parallel by several organizations. Contacts between EDOs are influenced by personal relations and are less formal; the actors know each other but the number of cooperation interfaces is limited; deeper understanding on the demand side of development services can improve the outcome.

\section{LITERATURES ABOUT LOCAL ECONOMIC DEVELOPMENT}

\section{Theory of local economic development - relevant approaches}

There are a number of definitions of local economic development (e.c.: Bajmócy, 2011; Mezei, 2006a; Lengyel, 2010; Swinbrun et al., 2004; Kane, 2004; Nafziger, 2012; Pike et al., 2006; Canzanelli, 2001). In summary, local development is a process through which participants contribute to improve the economic performance of a local region through various tools.

Local economic development is implemented as conscious intervention that affects the operation of the local economy. Local actors have roles as initiatives, targets, supporters or modifiers (Mezei, 2006b, 414). Its goal is to build up the economic capacity of a given territory in order to ensure the appropriate quality level of live for the local society and to ensure the future of the local economy. We can say that local economy is the continuous improvement of the local quality of life (Swinbrun et al., 2004). Local means a given territory and its surroundings (e.g.: districts). When we define the strategy of local economic development we should highlight that local economic development is not independent of the socio-political environment of the local region. It is necessary to account for the local, 
regional, and national legal systems, taxation policies, environmental protection laws, and other global factors and prevailing trends (Swinbrun et al., 2004).

The primary goal of local development can be the economic growth, but - as we mentioned at the beginning - there are several other that should be addressed, as listed below: (Mezei, 2006a; Czene et al., 2010):

- solving political and social problems,

- improving the quality of life,

- increasing the access to services,

- improving the relation of urban and rural territories,

- increasing the population retention capacity,

- activate local communities.

According to Bajmócy (2011) economic development may adopt any or all of the following strategic directions: creation of new workplaces, the improvement of the innovation capacity, changing the related institutional structure. To this list we would like to add the entrepreneurship development ${ }^{16}$ and the formation of the local financial and law systems. Other notable aspect is that local economic development affects the whole economy in general and effects local enterprises (Bajmócy, 2011). For instance, consider the following:

- General effects on the economy: creation of workplaces, increasing GDP, improving business environment, innovation skills, increasing salaries, number of firms.

- Effects on enterprises: increasing the value of the firm, income and number of employees, improving the business culture.

\section{Tools and actors of local economic development}

There are several authors, who have stated that it is a difficult task to identify the system of tools of the local economy, because these tools are diverse and there are several combinations. Tools appropriate for a given territory depend on the condition of its economy, the qualification of the local actors, the disposable time, and the financial and HR resources. In this paper we provide a short overview of the tools and the actors, without getting into details. $^{17}$ Table 1 shows a grouping of potential tools (Kullman, 2009).

\footnotetext{
${ }^{16}$ Development of enterprises is not equal to economic development. Development of enterprises is the part of economic development. Its goal is the improvement of the operation and capacity of enterprises.

${ }^{17}$ Detailed introduction is beyond the scope of this paper.
} 
Table 1 Grouping of tools of economic development

\begin{tabular}{|c|c|c|}
\hline \multirow{17}{*}{ 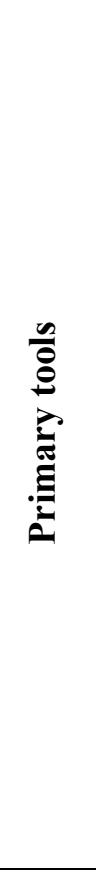 } & \multirow{4}{*}{ Benefits } & Tax benefits for investments \\
\hline & & Duty free zones \\
\hline & & (free) Enterprise zones \\
\hline & & Tax benefits for investments \\
\hline & Supports & Grant \\
\hline & \multirow{5}{*}{ Financial Tools } & Soft loan \\
\hline & & Microcredit \\
\hline & & Credit guarantee \\
\hline & & Interest subsidy \\
\hline & & Venture capital \\
\hline & \multirow{3}{*}{ Special Tools } & $\begin{array}{lll}\begin{array}{l}\text { Investments } \\
\text { organizations }\end{array} & \text { of } & \text { public } \\
\end{array}$ \\
\hline & & Governmental purchases \\
\hline & & Local trademark \\
\hline & \multirow{4}{*}{$\begin{array}{l}\text { Infrastructure of } \\
\text { firms }\end{array}$} & Industrial park \\
\hline & & Incubator \\
\hline & & Science park \\
\hline & & Innovation centre \\
\hline \multirow{2}{*}{ 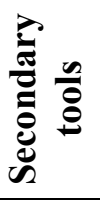 } & & Cluster \\
\hline & & Regional development program \\
\hline
\end{tabular}

Source: Kullmann, 2009, p. 10-12

Using Kullmann's grouping we developed the following tools which can be significant in the development process of a given territory:

- Financial instruments

- Supply of sites

- Education and vocational education

- Business breakfasts

- (Business) coaching

- Development of tourism

- Development of enterprises

There are additional issues to be addressed. For example, who will be the initiator and the implementer of the developing process? The potential candidates can include the follows based on our context: state, local government, enterprises (local, foreign), non-profit organizations, educational institutions, industrial parks, clusters, other organizations. There are common characteristics in these actors. Their normal activities effect local economic development. Beside them, there are organizations, which were created right up to use specific tools and apply concrete methods which lead to local economic development. These are the group of EDOs. 
There are particular organizations belonging to this group, which are coordinating other local developer actors. They are transferring legal, financial and technical information as a forum of local economy. This role is useful, because the level of duplication among development services can be reduced. So the rationalization of the local development can be achievable in a given territory. EDOs can function as firms or non-profit organisations depending on the activity and the types of services they offer.

Other important issue is the way of analysing the activity of EDOs. Empirical studies have already taken place in cities of similar size to Györ. Thus we can observe the methodology of the analysis about Ingolstadt automotive centre (Fekete 2014) or about the Rhein-Neckar metropolitan region (Schmitz 2005). Based on them, semi-structured interviews, strategic and descriptive operational documents are used as analysing tools.

\section{ECONOMIC DEVELOPMENT ORGANIZATIONS (EDOS) IN GYŐR}

\section{Methodology}

We have taken a comprehensive overview about relevant actors dealing with economic development activities in the town of Györ, Hungary and explored their service activities provided to economic actors. As it was mentioned in the introduction we have made semistructured interviews with 14 actors (EDOs) between May and August 2015.

The interviews were conducted orally and were recorded; also, additional information was obtained from the webpage of organizations.

Aim of the research was reached successfully as the interviewed organizations accounted for all EDOs in Györ in 2015. These organizations included economic and nonprofit organizations, and local governmental organizations regarding their organizational forms.

The interview questions took into consideration the following dimensions ${ }^{18}$ :

1. Supply map: information about functions and provided services of the organizations.

2. Relations of EDOs: tools were collected and categorized, which are applied by EDOs in order to contribute to the local economic development. They answered for the question that what kind of cooperation and relation they possess with other actors of the settlement.

3. Opinion about the local economic development of Györ;

4. Information about human trainings and scientific background.

\footnotetext{
${ }^{18}$ There was no database about economic development organizations functioning in the town of Györ, therefore, the list was created by direct observations, pilot interviews and suggestions made by other EDOs.
} 


\section{Services of EDOs in Győr}

Based on the interviews, we classified EDOs' activities into 5 categories (in case on two categories subcategories were also defined), which are the main supply groups of the economic development organizations (see Table 2). Categories were conducted based on the answers given by EDOs, some of them are not in the defining literature.

Table 2 Offer of economic development services in Győr by categories

\begin{tabular}{|c|c|c|c|}
\hline \multicolumn{3}{|r|}{ Categories } & $\begin{array}{l}\text { How many organizations } \\
\text { provide the given service }\end{array}$ \\
\hline 1. Training & 1. & Training & 3 \\
\hline \multirow[b]{2}{*}{ 2. Financing } & 2.1. & Refundable financing (lending) & 1 \\
\hline & 2.2. & $\begin{array}{l}\text { Non-refundable financing (EU and } \\
\text { central sources) }\end{array}$ & 3 \\
\hline \multirow{4}{*}{$\begin{array}{c}\text { 3. Services } \\
\text { supporting } \\
\text { current activities }\end{array}$} & 3.1. & $\begin{array}{c}\text { Services improving the } \\
\text { quality/volume of } \\
\text { trade/manufacturing activities }\end{array}$ & 11 \\
\hline & 3.2. & Services fostering business relations & 6 \\
\hline & 3.3. & $\begin{array}{l}\text { Services supporting initial/young } \\
\text { business activities }\end{array}$ & 5 \\
\hline & 3.4. & $\begin{array}{l}\text { Consulting (strategic, financial, } \\
\text { accounting, etc.) }\end{array}$ & 9 \\
\hline $\begin{array}{c}\text { 4. Project } \\
\text { management }\end{array}$ & 4. & Project management & 3 \\
\hline 5. Events & 5. & Organization of events & 3 \\
\hline
\end{tabular}

Source: own table based on interviews in 2015

It can be stated that services they improve, the quality/volume of trade/manufacturing activities and consulting activities (strategic, financial, accounting, etc.), are provided by most organizations. There were five organizations that did not offer their services directly to companies. Their functioning can be defined as indirect economic development activities.

\section{Relations of the EDOs and their opinions about local economic development}

Main statements regarding EDOs in Győr and their supply are listed in the following points ${ }^{19}$ :

- Organizations provide a wide-range of services.

- Financial services are offered by only a few organizations $(\mathrm{N}=3)$, however, consulting and services improving the quality/volume of trade/manufacturing activities are offered by almost all of them $(\mathrm{N}=9$ and $\mathrm{N}=11)$.

- The majority of services are not differentiated according to e.g. company size, activities or ownership (family business, ratio of foreign ownership).

\footnotetext{
${ }^{19}$ We think that a list form of introducing the main statements are an appropriate style.
} 
- Local government provides its coordinating role.

- There are organizations in which the role of local government or government is significant, e.g. local government acts as an owner in many EDOs. It should be highlighted that EDOs also have ownerships in other economic development organizations in the town.

- The vocational education and higher education contribute considerably to the development of Györ economy by providing supply adjusted to the demand. However, previous studies show (e. g. Kovács-Reisinger 2014) that family sample is more important for students studying in higher educational institutions than trainings in institutions.

- The EDOs suggest that the biggest problem of Györ and its region is the lack of qualified workforce; and they do not know any solutions yet. Several organizations did former steps (e.g. attracting workforce from other parts of the country) but with limited success. They faced that if somebody comes to Györ from Eastern Hungary, will move to Austria or Germany by taking into account higher income opportunities.

- The Industrial Park of Györ is a determinate actor in the town with more than 100 settled companies and extensive services.

- The collaboration of EDOs with other actors is characterized by informal ties and in many cases ad hoc initiatives. The cooperation is related rather to persons and not to organizations.

- Almost every organization possesses different relations with the Széchenyi István University.

- The congruent opinion of EDOs is that Györ and its development proceeds in the right direction, though there are factors which should be brought to the fore in the future:

$>$ There is a need for closer collaboration of the town and its region.

$>$ It would be expedient to establish a coordinating institution of economic development activities.

$>$ The presence of Audi offers on one hand positive factors (job creation, relations, suppliers' network, etc.), on the other hand its workforce drain effect is significant and smaller firms are unable to compete with the multinational company regarding wages.

$>$ The problem of generation change is present in family businesses in the town; however, only one organization mentioned it. 


\section{Opinion of EDOs about human trainings and scientific background}

Beside the evaluation of the supply services offered by EDOs, we wanted to recognize the EDOs' opinion about personnel trainings and scientific background in Győr. Two dimensions were defined:

- How important would the given factor be from the aspect of Györ's economic development?

- How satisfied are EDOs with the given service in Györ?

This topic is relevant as the status of human resources is a key milestone in the improvement of economic development activities. It could offer support for both companies and training institutions. Table 3 shows the judgement of the interviewed EDOs ( 8 organizations answered these questions) regarding human trainings and scientific background.

Table 3 Attitudes of the economic development organizations towards human training and scientific background, $1=$ not at all; $5=$ fully

\begin{tabular}{|c|c|c|c|}
\hline Factors & $\begin{array}{l}\text { How important would } \\
\text { the given factor be from } \\
\text { the aspect of Győr's } \\
\text { economic development? } \\
\text { Mean }\end{array}$ & $\begin{array}{c}\text { How satisfied are } \\
\text { you with the given } \\
\text { service in Györ? } \\
\text { Mean }\end{array}$ & $\begin{array}{c}\text { Difference } \\
\text { between } \\
\text { means }\end{array}$ \\
\hline Vocational training & 4.75 & 4.00 & 0.75 \\
\hline Technical higher education & 4.75 & 4.38 & 0.38 \\
\hline $\begin{array}{l}\text { Leadership and economic trainings } \\
\text { and further trainings }\end{array}$ & 4.00 & 3.29 & 0.71 \\
\hline $\begin{array}{l}\text { Trainings specialized in automotive } \\
\text { industry }\end{array}$ & 4.38 & 4.00 & 0.38 \\
\hline $\begin{array}{l}\text { Foreign language trainings } \\
\text { specialized in automotive industry }\end{array}$ & 4.00 & 3.29 & 0.71 \\
\hline $\begin{array}{l}\text { Competence development trainings } \\
\text { (communication, conflicts } \\
\text { management, presentation, debate } \\
\text { culture, project management) }\end{array}$ & 3.88 & 3.29 & 0.59 \\
\hline General foreign language trainings & 4.75 & 3.29 & 1.46 \\
\hline $\begin{array}{l}\text { R\&D services in the region } \\
\text { available for companies (involving } \\
\text { researchers acknowledged on } \\
\text { international level) }\end{array}$ & 4.13 & 2.88 & 1.25 \\
\hline $\begin{array}{l}\text { Access of companies to } \\
\text { international quality laboratory } \\
\text { devices for marketable price }\end{array}$ & 4.38 & 2.63 & 1.75 \\
\hline Support of marketable start-ups & 4.50 & 2.63 & 1.88 \\
\hline
\end{tabular}

Source: own table based on interviews in 2015 
Based on the interviews, the most important factors are vocational training, technical higher education and general foreign language trainings regarding the economic development of Györ (mean=4.75); the less important is competence development trainings. Although this factor has the lowest mean (=3.88), its importance is not negligible. Moreover, it can be one of the most relevant factors since the development of competencies (through trainings, workshops or business coaching) can be influenced by the competitiveness of the business sphere and in the economic development.

Regarding the satisfaction, the interviewed organizations are the most satisfied with technical higher education, and the least satisfied with the support marketable start-ups and the access of companies to international quality laboratory devices for marketable price.

The average difference is 1 between the importance of the given factor and its present status. The biggest difference is seen between reality and importance in the case of support marketable start-ups. The importance of this factor is 4.50 ; the reality is 2.63 , thus, the support of start-ups need improvement. An effective institution system will be useful; this is highlighted in the final section of this article. The support of start-ups and business activities based on creative ideas has bigger chance in a dynamically developing economic area of Györ.

There is also a significant difference between the access of companies to international quality laboratory devices for marketable price and how important it would be. The lowest difference is in two cases, technical higher education and trainings specialized in the automotive industry. The interviewed EDOs has recognized and identified the opportunities, which cover special personnel trainings. In most of the cases they classify these trainings significant in further and sustainable economic development in Győr. However, EDOs are not satisfied with the given infrastructure; it should be improved.

\section{SWOT ANALYSIS OF ECONOMIC DEVELOPMENT SUPPLY}

Based on the collected information we defined items of a SWOT analysis. It is important to review the strengths and weaknesses by which the potential of actively participating actors in the local economic development can be determined. Opportunities and threats will be presented both on the short and long run. We provide the SWOT analyses as a part of our results not as a conclusion. Our statements are referred to the city of Györ, but some of them can be appropriate to other settlements, too. 


\section{Strengths:}

- Primary and secondary tools categorized by Kullmann (2009) are present in economic development services.

- Years of experience on the own service field.

- Every organization is able to identify its opportunities and threats.

- Relation with higher educational institutions is close and live.

- Active benchmarking activity.

- Organizations related to local government possess strong coordinating functions.

- There are services that support directly the companies' manufacturing and/or trading activities.

\section{Weaknesses:}

- Isolated functioning of organizations - lack of building cooperation and networks.

- Lack of communicational interfaces.

- Intensity of communication, type and strength of relations.

- Ad hoc contacts.

- Although organizations are aware of their opportunities and threats they do not take effective steps or are unable to take steps.

- Lack of an organization uniting EDOs.

- Overlaps between service supply - parallelism.

- In the toolkit of economic development there are special services which are missing in the services provided by EDOs in Györ or of which presence is weak (e.g. business coaching).

- Alternative services are missing which deal with special problems of firms (e.g. generation change, search for appropriate workforce, lack of services offered to micro firms).

- Personal relations are dominant regarding collaborations; thus, services of EDOs do not reach uniformly every actor in the business sector.

\section{Opportunities - Short-term ${ }^{20}$ :}

- Building relationships between EDOs.

- Forming communication channels between EDOs and between EDOs and companies.

\footnotetext{
${ }^{20}$ Even there are similarities in the long and short term list we hold it important to make differences between them.
} 
- Building relations with foreign companies.

- Differentiated communication based on company size.

- An intermediary and coordinating institution would support interviewed EDOs to work more effectively.

\section{Opportunities - Long-term:}

- Building relationships between EDOs.

- Forming communication channels between EDOs and between EDOs and companies.

- Building relations with foreign companies.

- Strengthening cross-border interactions.

- Differentiated communication based on company size.

- Formation of an institution which converge every EDO.

- An intermediary and coordinating institution would support interviewed EDOs to work more effectively.

- Preparing a detailed local 'company map' would support the improvement of EDOs' services by methodizing the functioning companies in Györ.

\section{Threats - Short-term:}

- Lock-in - organizations keep in touch with past relations; therefore, obstruct themselves from opportunities, development and new relations.

- Overlaps between service supplies.

- The majority of EDOs do not deal with the problem of generation change or other specific problems in family businesses.

- Foreign companies will remain unknown if EDOs do not map them.

- The long-term effective functioning of business development organizations could become difficult as they offer ad hoc and project-related service packages.

- The effectiveness of EDOs could decrease if there will not be any coordinating institutions.

\section{Threats - Long-term}

- Lock-in - organizations keep in touch with past relations; therefore, obstruct themselves from opportunities, development and new relations.

- Overlaps between service supplies.

- The majority of EDOs do not deal with the problem of generation change or other specific problems in family businesses. 
- Some organizations' functioning will be impossible (e.g. organizations offering few services).

- There are only a couple of EDOs of which services are related to micro firms. The improvement of significant micro business base could foster and multiply the economy. The lack of it could slow down this process.

- The effectiveness of EDOs could decrease if there will not be any coordinating institutions.

\section{CONCLUSION AND RECOMMENDATIONS}

The aim of our paper was to analyse the kinds of local development services available in Györ, Hungary, and to process their context. Such a survey has not been made in this region before. We set out to contribute to the literature of local economic development by representing the regional supply map.

In order to this we made detailed interviews with 14 organizations in the summer of 2015. We defined the services, depicted the cooperative attributes of EDOs, and described the context of their services. Based on this and our previous experiences we could make the SWOT analyses of the supply of local development services. In order to keep the strengths, explore the opportunities, fix the weaknesses and avoid the threats in the following points we concluded the following suggestions ${ }^{21}$ :

- Although all organizations provide a range of local development services, these are not complementing each other; they lead to competitive situation. Decreasing the level of duplication would be an important goal in the future. Restructuring of the supply map would be necessary for appropriate division of labour among these organizations.

- The service range offered by EDOs addresses a broad range of companies, but due to the fact that companies are highly heterogeneous - especially in aspect of sectoral classification, scope of activity, location and size - it would be necessary to segment them. Through segmentation, the demand side of local economic development, especially the development of enterprises, can be more visible. This could ease the effective development processes. Segmentation among size is suggested in the theory. Micro, small and medium sized companies often create one group. Our opinion is that this methodology cannot be applied successfully in the research of the

\footnotetext{
${ }^{21}$ We interpret them in a list form.
} 
local development services. Micro enterprises need different services than small and medium ones. We can say that they need different EDOs. With respect to a given EDO, it would be important to diversify services according to given variables: size, location, performance, industrial sector.

- The organizations involved in the research are aware of the available local development services in Györ. They know each other. There is less formal cooperative activity between them. Networking and cooperative activities are necessary in order to realize dynamic development in the future. Although the majority of these organizations evaluate their relation very well with educational institutions, concrete cooperation did not happen between them.

- Liaison between the organizations is most frequently among persons. It is limited to communication. Unfortunately the organizational-level dialogue is seldom reached. This is needed, especially between the leaders of the organizations.

- There is a lack of dialogue observed, not only among economic development organizations, but also with the target audience - companies and firms. Communication to existing customer base is properly going on, but there is more potential on the demand side. It means, the demand is bigger and more differentiated. These are the organizations that are outside the scope of the vision of EDOs. Facility of the communication with them is minimal. This was acknowledged by several participants as well.

- Communication is needed for building up relations, realizing cooperation, and the appropriate division of labour. Increasing communicational platforms would help. This would ensure the meeting point of organizations for personal and online interactions as well. Beside these on one hand we can name platforms like different forums, special conferences targeting EDOs and workshops, where these actors can share own experiences and have the opportunity to find solutions for the potential problems and difficulties, or finding some new opportunities. On the other hand other important platform of communication would be the virtual world. Creating an online platform would have two main advantages: it would linked EDOs, which are operating with similar activities. Other important advantage would be, that through the virtual platform EDOs and their services would be more visible for companies and firms. This visibility would connect the supply to the demand. 
- Helping start-ups is an important factor because it is dynamically developing economy of Györ, increasing the chances of rapid development in entrepreneurial activities based on creative ideas. Creation of a company is regularly supported in the framework of EU projects. Support of start-up companies, by itself, is not a profitable service. We do not suggest providing such support under one EDOs framework. A supplementary service is needed, which can be one of the functions of higher education institutions.

- Ongoing analysis, consistent management and the coordination targeting EDOs should have a complex function. Based on Györ's case we would suggest this function for universities. Higher education institutions are central actors, reaching a lot of people from the labour supply and demand side alike. With this function higher education would carry out a mediator role between the two before mentioned sides, the EDOs and the companies.

\section{Acknowledgement}

This paper is based on the following project: „Györ Megyei Jogú Város Integrált Területi Programja (ITP) megvalósítása előkészítésének szakmai támogatására, valamint Győr Megyei Jogú Város gazdaság és innováció fejlesztési tevékenységeit megalapozó tanulmányok és koncepciók elkészítésére - TÁMOP4.2.1.C-14/1/KONV-2015-0005"

\section{REFERENCES}

Bajmócy, Z. (2011). Bevezetés a helyi gazdaságfejlesztésbe. (Introduction of the local economic development.) Szeged: JATEPress.

Canzanelli, G. (2001). Overview and Learned Lessons on Local Economic Development, Human Deveopment, and Decent Work. ILO Working Paper, Geneva. www.ilo.org Downloaded: 11.04. 2008.

Czakó, K. (2017). Vállalkozásfejlesztés és a területi tőke relációja - A felsőoktatási intézmények szerepe. (Relation of Entrepreneurship Development and Territorial Capital - Role of Higher Education Institutions.) Benyújtott doktori értekezés. Győr: Széchenyi István Egyetem.

Czene, Zs., Horkay N., \& Ricz J. (2010). Röviden a helyi gazdaságfejlesztésről. (Shortly about the local economic development.) In Czene Zs., Ricz J. (Eds.), Helyi gazdaságfejlesztés (pp. 13-28). Területfejlesztési füzetek (2). Budapest: Nemzeti Fejlesztési Minisztérium, Nemzetgazdasági Minisztérium, VÁTI.

Fekete, D. (2014). Gazdaságfejlesztés az ingolstadti jármüipari központban.(Economic development in the automotive centre of Ingolstadt.) Tér és társadalom, (28)2, 176-187.

Kane, M. (2004). Public-Sector Economic Development: Concepts and Approaches. Northeast-Midwest Institute. Retrieved from http://www2.econ.iastate.edu Downloaded: 10. 05. 2015. 
Kovács N., \& Reisinger A. (2014). Felsőoktatási hallgatók karrierelvárásait befolyásoló tényezők feltérképezése. (A survey of the influential factors of students' entrepreneurial career choice expectations.) Társadalomkutatás, (32)3, 278-294.

Kullmann, Á. (2009). A regionális gazdaságfejlesztés eszközrendszere és magyarországi alkalmazása. (The tools of the regional economic development and its applying in Hungary.) Doktori értekezés. Budapest: Eötvös Loránd Tudományegyetem, Természettudományi Kar.

Lengyel, I. (2010). Regionális gazdaságfejlesztés. (Regional economic development.) Budapest: Akadémiai Kiadó.

Mezei, C. (2006a). A helyi gazdaságfejlesztés fogalmi meghatározása. (Definition of the local economic development.) Tér és Társadalom, (20)4, 85-96.

Mezei, C. (2006b). A települések versenyképességét befolyásoló helyi gazdaságfejlesztési gyakorlat Magyarországon. (Practice of local economic development in Hungary affecting the competitiveness of settlements.) In Horváth Gy. (Ed.), Régiók és települések versenyképessége (pp. 413-442). Pécs: MTA RKK.

Nafziger, E. W. (2012). Economic Development. Oxford: Cambridge University Press.

Pike, A., Rodriguez-Pose, A., \& Tomaney, J. (2006). Local and Regional Development. London and New York: Routledge.

Rechnitzer, J. (2016). A területi tőke a városfejlődésben - A Győr Kód. (Territorial Capital and urban develpoment - Code of Györ) Budapest-Pécs: Dialog Campus Kiadó.

Schmitz, G. (2005). Metropolregion Rhein-Neckar - Modellregion für einin kooperativen Föderalismus. Ramuforschung und Raumordnung, 5. 360366.

Swinburn, G., Goga, S. \& Murphy, F. (2004). A helyi gazdaságfejlesztés kézikönyve. (Handbook of local economic development.) Washington, D.C.: The World Bank; London: Bertelsmann Stiftung. 